\title{
Pengaruh Struktur Modal dan Keberadaan Komite Pengawas Manajemen Terhadap Kebijakan Dividen (Studi Empiris Pada Perusahaan Food and Beverage Di Indonesia Tahun 2014-2016 Yang Terdaftar di BEI)
}

\author{
Dinalestari Purbawati ${ }^{1, *}$, Rodhiyah ${ }^{2}$ \\ ${ }^{1,2}$ Departemen Administrasi Bisnis, Fakultas Ilmu Sosial dan Ilmu Politik, Universitas Diponegoro \\ "Email: dinapyu@gmail.com
}

\begin{abstract}
This study examined the impact between capital structure and existence of an oversight committee to dividend policy. The oversight committee such as risk management committee, nominations and remuneration committee. Data was collected from the annual reports food and beverage companies listed on the Indonesian Stock Exchange (BEI) the period 2014, 2015 and 2016. Analysis tools used multiple regression. The results showed that the variable capital structure and risk management committee has a significant effect on dividend policy. The simultan test showed that capital structure and oversight committee has a significant effect on dividend policy.
\end{abstract}

Abstraksi Studi ini meneliti dampak antara struktur modal dan keberadaan komite pengawasan terhadap kebijakan dividen. Komite pengawasan seperti komite manajemen risiko, komite nominasi dan remunerasi. Data dikumpulkan dari laporan tahunan perusahaan makanan dan minuman yang terdaftar di Bursa Efek Indonesia ( BEI) periode 2014, 2015 dan 2016. Alat analisis menggunakan regresi berganda. Hasil penelitian menunjukkan bahwa variabel struktur modal dan komite manajemen risiko memiliki pengaruh signifikan terhadap kebijakan dividen. Uji simultan menunjukkan bahwa struktur modal dan komite pengawasan memiliki pengaruh signifikan terhadap kebijakan dividen.

\section{Keywords: Corporate Governance; Dividend Policy; Nominations and Remuneration Committee; Oversight Committee; Risk Management Committee}

\section{Pendahuluan}

Entitas bisnis selalu memiliki tujuan yang perlu dicapai. Salah satu tujuan utama suatu entitas bisnis adalah perolehan laba secara optimal. Menurut Sjahrial (2002:305), perusahaan akan mengalami proses tumbuh dan berkembang, serta akan memperoleh keuntungan atau laba. Laba terdiri dari laba yang ditahan serta laba yang dibagikan. Perolehan laba akan berpengaruh terhadap ekspektasi serta penilaian para pemangku kepentingan atas perusahaan. Pada tahap selanjutnya, laba yang ditahan merupakan salah satu sumber dana yang paling penting untuk pembiayaan pertumbuhan perusahaan. Makin besar pembiayaan perusahaan yang berasal dari laba yang ditahan di tambah penyusutan asset tetap, maka semakin kuat pula kondisi keuangan perusahaan tersebut. Sebagian dari keseluruhan laba yang diperoleh perusahaan akan dibagikan kepada pemegang saham berupa dividen. Penentuan besarnya dividen yang akan dibagikan kepada para pemegang saham merupakan suatu kebijakan dividen yang dibentuk oleh pimpinan perusahaan.

Return dan risiko yang di hadapi oleh pemegang saham akan dipengaruhi oleh struktur finansial/modal, maka penggunaan leverage secara potensial akan mempengaruhi biaya modal perusahaan. Keputusan pemilihan sumber dana jangka pendek maupun jangka panjang yang digunakan akan berpengaruh terhadap struktur modal (Sartono, 2005).

Perubahan struktur modal dapat menyebabkan perubahan nilai perusahaan yang dapat diukur dari harga saham atau biaya modal yang dikeluarkan dalam memperoleh sumber dana yang bersangkutan.

Aspek modal yang tercermin pada struktur modal, serta aspek pengawasan yaitu keberadaan komite pengawas manajemen akan berpengaruh terhadap kebijakan dividen yang dilakukan perusahaan. Perbedaan proporsi pada struktur modal serta keberadaan 
komite pengawas manajemen akan mengakibatkan perbedaan kebijakan dividen yang dilakukan antara masing-masing perusahaan. Kebijakan dividen yang efektif akan memberikan sinyal positif mengenai prospek perusahaan. Kebijakan dividen terkait erat terhadap profitabilitas perusahaan, sehingga kebijakan dividen dapat merefleksikan secara handal gambaran keuangan perusahaan. Fenomena tersebut akan mendorong penciptaan kepercayaan investor terhadap perusahaan. Terciptanya kepercayaan investor akan berdampak pada perkembangan perusahaan ke depan.

Perusahaan food and beverage juga tidak terlepas dari fenomena tersebut. Sektor industri food and beverage diprediksi memiliki prospek yang baik, akan tetapi berfluktuasi pada pertumbuhan laba dan arus kas operasi, sehingga menarik untuk dilakukan kajian lebih lanjut.

Penelitian ini akan menguji pengaruh antara struktur modal dan keberadaan komite pengawas manajemen terhadap kebijakan dividen pada perusahaan food and beverage yang go public di Indonesia.

\section{Kajian Teori}

\section{Teori Struktur Modal}

Teori struktur modal digunakan untuk mengetahui apakah perusahaan bisa meningkatkan kemakmuran pemegang saham melalui perubahan struktur modal. Analisis struktur modal bisa dilakukan dengan melihat besarnya nilai perusahaan atau biaya modal, bila tujuan perusahaan adalah meningkatkan nilai perusahaan artinya sama dengan menurunkan biaya modal (Sutrisno, 2012).

\section{Teori Agensi}

Menurut Jensen dan Meckling (1976), teori keagenan mendeskripsikan pemegang saham merupakan prinsip dan manajemen sebagai agen. Dalam teori agensi muncul konflik kepentingan antara prinsipal dan agen karena termotivasi oleh kepentingan masingmasing.
Komite bentukan dewan komisaris merupakan merupakan kepanjangan tangan dari dewan komisaris sebagai prinsipal untuk melakukan pengawasan terhadap manajemen selaku agen. Dewan komisaris berharap dengan adanya pengawasan yang dilakukan oleh komite bentukannya, manajemen (agen) dapat berperilaku atau bertindak sesuai dengan yang diharapkan oleh dewan komisaris selaku prinsipal.

\section{Signalling Theory}

Teori sinyal menyatakan bahwa manajer menggunakan akun-akun (accounts) untuk memberikan sinyal terhadap harapan dan tujuan di masa depan. Konsekuensi logis dari teori persinyalan, manajer-manajer terdorong untuk mensinyalkan harapan masa depan, salah satunya melalui kebijakan dividen yang efektif. Kebijakan yang efektif diharapkan akan menciptakan kepercayaan serta persepsi positif investor akan nilai perusahaan, sehingga akan berpengaruh pula terhadap kondisi finansial perusahaan.

Kerangka teoritis yang dibangun untuk penelitian ini adalah sebagai berikut:

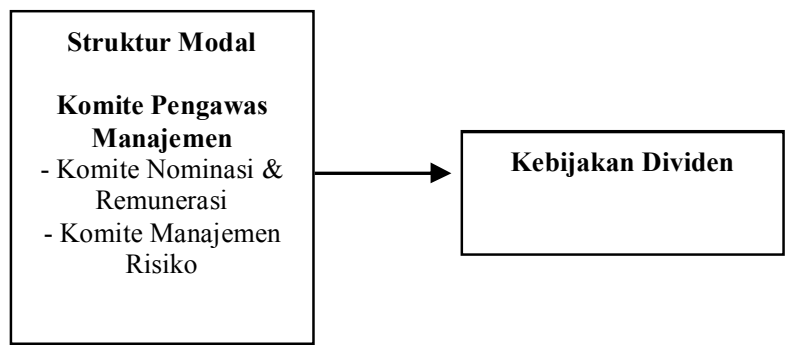

\section{Gambar 1. Kerangka teoritis}

Sumber: Dikembangkan untuk penelitian ini.

\section{Hipotesis}

H1: Struktur modal berpengaruh terhadap kebijakan dividen.

H2: Keberadaan komite manajemen risiko berpengaruh terhadap kebijakan dividen. 
H3: Keberadaan komite nominasi dan remunerasi berpengaruh terhadap kebijakan dividen.

H4: Struktur modal, keberadaan komite manajemen risiko serta komite nominasi dan remunerasi secara simultan berpengaruh terhadap kebijakan dividen.

\section{Metode}

Penelitian ini dilakukan untuk menguji hipotesis (hypothesis testing) dengan melakukan pengujian hubungan terhadap semua variabel yang diteliti (causal research). Dimensi waktu riset melibatkan satu waktu tertentu dengan banyak sampel (cross sectional). Data yang digunakan adalah data sekunder. Penelitian ini termasuk penelitian eksplanatori (explanatory research) yaitu mencari penjelasan atau menguji pengaruh antar variabel yang dirumuskan pada hipotesis penelitian. Informasi yang diperoleh, digunakan untuk mengeneralisir temuan dari sampel yang diambil dari populasi (Sekaran, 2000).

Populasi dalam penelitian ini meliputi perusahaan Food and Beverage yang terdaftar di Bursa Efek Indonesia pada periode tiga tahun terakhir 2014, 2015 dan 2016. Total keseluruhan sampel pada periode penelitian berjumlah 42 perusahaan. Pengambilan sampel dilakukan dengan metode purposive sampling. Perusahaan yang menjadi objek penelitian adalah perusahaan yang memenuhi beberapa kriteria tertentu, yaitu: (1) Perusahaan yang go public yang terdaftar secara berturut-turut di BEI pada periode tiga tahun terakhir yaitu tahun 2014, 2015, dan 2016; (2) Perusahaan yang termasuk dalam sektor food and beverage, jumlah 14 yang terdaftar di BEI.

Statistik deskriptif yang digunakan dalam penelitian ini adalah nilai rata-rata (mean), maksimum, dan minimum untuk menggambarkan variabel-variabel penelitian. Alat analisis yang digunakan untuk model pengujian pada penelitian ini adalah regresi linier berganda. Persamaan untuk model pengujian yang pertama sebagai berikut:

$$
(\mathrm{KD})=\alpha+\theta 1(\mathrm{SM})+\theta 2(\mathrm{KNR})+\theta 3(\mathrm{RMC})+\mathrm{e}
$$

\section{Hasil}

Hasil tabel 1 menunjukkan bahwa dari total sampel yang ada yaitu 42, rata-rata variabel SM adalah 0,67 atau dalam satuan persen adalah $67 \%$ dengan nilai terendah 0 dan nilai tertinggi 3. Kemudian nilai rata-rata variabel Dev_Policy adalah 11,2 dalam satuan persen (\%) dengan nilai terendah sebesar 4 dan nilai tertinggi sebesar 22 .

Tabel 1. Statistik Deskriptif

\begin{tabular}{|c|c|c|c|c|c|}
\hline & $\mathrm{N}$ & Min & $\operatorname{Max}$ & Mean & $\begin{array}{c}\text { Std. } \\
\text { Deviation }\end{array}$ \\
\hline $\mathrm{SM}$ & 42 & 0 & 3 & .67 & .612 \\
\hline Dev_Policy & 42 & 4 & 22 & 11.12 & 4.676 \\
\hline $\begin{array}{l}\text { Valid N } \\
\text { (listwise) }\end{array}$ & 42 & & & & \\
\hline
\end{tabular}

Sumber: Output SPSS, 2017

Tabel 2 menunjukkan adalah tabel hasil pengujian menggunakan regresi linier berganda.

Selanjutnya, persamaan regresi yang dihasilkan adalah sebagai berikut: $($ DEV POLICY $)=5,722+0,034 \mathrm{SM}+7,905$ RISK $^{-}+0,519$ NOM REMUN + e. Tabel 3 adalah tabel ringkasan mengenai hasil pengujian hipotesis.

\section{Pembahasan}

Berdasarkan hasil penelitian diketahui bahwa struktur modal berpengaruh terhadap kebijakan dividen. Struktur modal merupakan imbangan antara modal asing atau hutang dengan modal sendiri (Sutrisno, 2012). Proporsi modal asing dengan modal sendiri berpengaruh terhadap kebijakan dividen yang dikeluarkan oleh perusahaan. Investor sebagai salah satu penyedia modal memiliki harapan. Dividen merupakan ekspektasi investor akan suatu investasi yang ditanamkan pada perusahaan. Dividen berkaitan erat terhadap profitabilitas perusahaan. Oleh karena itu, kebijakan dividen yang dibentuk oleh perusahaan merupakan salah satu komponen yang dinilai oleh investor terkait prospektus perusahaan. 
Tabel 2. Hasil Pengujian Regresi Berganda

\begin{tabular}{lrrrrr}
\hline Model R & \multicolumn{2}{c}{ R Square } & Adjusted R Square & Std. Error of the Estimate & \multicolumn{2}{c}{$\begin{array}{c}\text { Durbin- } \\
\text { Watson }\end{array}$} \\
\hline 1 & $.748^{\mathrm{a}}$ & .560 & .525 & 3.223 & 1.241 \\
\hline
\end{tabular}

a. Predictors: (Constant), NOM_REMUN, SM, RISK

b. Dependent Variable: DEV_POLICY

Coefficients $^{\mathrm{a}}$

\begin{tabular}{|c|c|c|c|c|c|c|c|}
\hline \multirow[b]{2}{*}{ Model } & \multicolumn{2}{|c|}{$\begin{array}{l}\text { Unstandardized } \\
\text { Coefficients }\end{array}$} & \multirow{2}{*}{$\begin{array}{c}\text { Standardized } \\
\text { Coefficients } \\
\text { Beta }\end{array}$} & \multirow[b]{2}{*}{$\mathrm{t}$} & \multirow[b]{2}{*}{ Sig. } & \multicolumn{2}{|c|}{ Collinearity Statistics } \\
\hline & B & Std. Error & & & & Tolerance & VIF \\
\hline 1 (Constant) & 5.722 & 1.231 & & 4.648 & .000 & & \\
\hline SM & .034 & .853 & .969 & .039 & .004 & .931 & 1.074 \\
\hline Risk & 7.905 & 1.268 & .773 & 6.235 & .000 & .754 & 1.327 \\
\hline Nom_Remun & .519 & 1.117 & .056 & -.465 & .645 & .795 & 1.257 \\
\hline
\end{tabular}

a. Dependent Variable: DEV_POLICY

ANOVA $^{\mathrm{b}}$

\begin{tabular}{llrrrrr}
\hline Model & Sum of Squares & Df & Mean Square & F & \multicolumn{1}{c}{ Sig. } \\
\hline 1 & Regression & 501.708 & 3 & 167.236 & 16.101 & $.000^{\mathrm{a}}$ \\
Residual & 394.697 & 38 & 10.387 & & \\
Total & 896.405 & 41 & & & \\
\hline
\end{tabular}

a. Predictors: (Constant), NOM_REMUN, SM, RISK

b. Dependent Variable: DEV_POLICY

Sumber: Hasil Output SPSS (2017)

Terkait dengan faktor pengawasan, dewan komisaris memiliki kepanjangan tangan dalam fungsi pengawasan yaitu dengan keberadaan komite pengawas manajemen. Komite pengawas manajemen terkategori dalam komite manajemen risiko serta komite nominasi dan remunerasi. Efektifitas komite manajemen risiko diharapkan akan mampu meminimalisir risiko yang akan berdampak terhadap nilai perusahaan. Salah satu cara menciptakan nilai positif akan perusahaan, yaitu melalui kebijakan dividen. Dengan demikian, keberadaan komite manajemen risiko yang efektif dapat membantu perusahaan mencapai tujuan usahanya, meningkatkan nilai dan menjaga reputasi perusahaan dimata para stakeholder.

Sedangkan, berdasarkan tugas dan tanggung jawab komite nominasi dan remunerasi lebih berfokus pada kebijakan lingkup internal perusahaan, sehingga tidak mempengaruhi kebijakan bagi eksternal seperti pembentukan kebijakan dividen.

Secara bersama-sama kedua faktor tersebut menjadi perhatian investor, karena memegang peranan terhadap pembetukan kebijakan dividen. Dalam usaha terbentuknya kebijakan dividen yang sesuai dengan harapan investor, perusahaan dipengaruhi oleh struktur modal yang menyusun serta keberadaan dari komite pengawas manajemen. Kedua faktor tersebut merupakan sinyal yang dapat digunakan oleh investor dalam kepentingan untuk pengambilan keputusan berinvestasi.

\section{Kesimpulan dan Saran}

Bagi investor struktur modal yang dimiliki oleh perusahaan dan keberadaan komite pengawas manajemen dapat digunakan sebagai sinyal akan kebijakan dividen yang akan dibuat oleh perusahaan tersebut. Struktur modal akan mempengaruhi jumlah laba perusahaan. Perusahaan dengan laba yang 
tinggi cenderung akan lebih percaya diri dalam membuat kebijakan, yaitu kebijakan untuk membagi dividen dengan nilai yang tinggi pula. Keberadaan komite pengawas manajemen akan membantu menciptakan pelaksanaan mekanisme good corporate governance.

Tabel 3. Ringkasan Hasil Uji Hipotesis

\begin{tabular}{|c|c|c|c|}
\hline No. & Hipotesis & Signifikasi & Hasil \\
\hline 1. & $\begin{array}{l}\text { Struktur modal } \\
\text { berpengaruh } \\
\text { terhadap } \\
\text { kebijakan } \\
\text { dividen. }\end{array}$ & 0,004 & Diterima \\
\hline 2. & $\begin{array}{l}\text { Keberadaan } \\
\text { komite } \\
\text { manajemen } \\
\text { risiko } \\
\text { berpengaruh } \\
\text { terhadap } \\
\text { kebijakan } \\
\text { dividen. }\end{array}$ & 0,000 & Diterima \\
\hline 3. & $\begin{array}{l}\text { Keberadaan } \\
\text { komite } \\
\text { nominasi dan } \\
\text { remunerasi } \\
\text { berpengaruh } \\
\text { terhadap } \\
\text { kebijakan } \\
\text { dividen. }\end{array}$ & 0,645 & $\begin{array}{l}\text { Tidak } \\
\text { Diterima }\end{array}$ \\
\hline 3 & $\begin{array}{l}\text { Struktur } \\
\text { modal, } \\
\text { keberadaan } \\
\text { komite } \\
\text { manajemen } \\
\text { risiko serta } \\
\text { komite } \\
\text { nomiasi dan } \\
\text { remunerasi } \\
\text { secara } \\
\text { simultan } \\
\text { berpengaruh } \\
\text { terhadap } \\
\text { kebijakan } \\
\text { dividen. }\end{array}$ & 0,000 & Diterima \\
\hline
\end{tabular}

Sumber: Dikembangkan untuk penelitian ini.

Idealnya perusahaan akan berjalan dengan baik, sehingga mampu mencapai tujuan perusahaan. Salah satu tujuan perusahaan adalah laba. Perolehan laba yang tinggi akan mempengaruhi pembentukan kebijakan dividen bagi investor.

\section{Daftar Referensi}

Deegan, C. (2004). Financial Accounting Theory. Sydney: McGraw-Hill Book Company.

Francis, J., Nanda, D., \& Olsson, P. (2005). Voluntary disclosure, information quality, and costs of capital. Working paper. Durham, NC: Duke University.

Guthrie, J., and L. D. Parker. (1989). Corporate social reporting: a rebuttal of legitimacy theory. Accounting and Business Research. Vol. 19 No. 76. pp. 343-52.

Ho, S and Wong K. S. (2001). A Study of the Relationship Between Corporate Governance Structures and the Extent of Voluntary Disclosure. Journal of International Accounting Auditing and Taxation, vol 10.

Kangarlouei, et.al. (2013). The investigation of the effect of voluntary disclosure on earnings quality and cost of capital in firms listed in Tehran Stock Exchange. International Journal of Empirical Finance, Vol. 1, No. 1, 2013, pp. 1-6.
Khomsiyah. (2005). Analisis Hubungan Struktur dan Indeks Corporate Governance Dengan Kualitas Pengungkapan. Disertasi S3. Universitas Gadjah Mada.

Subramaniam, Nava, L. Mc. Manus, and Jiani Zhang. (2009). Corporate Governance, Firm Characteristics, and Risk Management Committee Formation in Australia Companies. Managerial Auditing Journal, Vol. 24, No. 4, pp. 316-339. 